\title{
"Unregulation" and Broadcast Financing: New Ways for the Federal Communications Commission To Serve the Public Interest
}

\author{
Nancy R. Selbst $\dagger$
}

Sixty-four years ago, Congress set out to regulate the broadcasting industry. The Radio Act of $1927,{ }^{1}$ and its successor, the Federal Communications Act of $1934,{ }^{2}$ created the Federal Communications Commission (FCC). Congress charged the FCC with regulating in the "public convenience, interest, or necessity." 3 The FCC, in turn, created specific regulations as well as more general policies to carry out its legislative mandate. Over the next few decades, it controlled ownership licenses and broadcast finance, restricted multiple ownership, oversaw station operations, issued guidelines for commercial and non-entertainment programming, and regulated in a host of other ways.

One such general policy governs the overlap of FCC policies with state and federal laws. The FCC accommodates other such laws when doing so does not conflict with the Communications Act; it has also altered many of its policies to make its regulations consistent with state and federal laws.

While this policy of accommodation has stayed constant over time, many other policies changed in the early 1980's, as the FCC began to see its role in a new light. In 1981, President Reagan appointed Mark Fowler to chair the FCC; ${ }^{4}$ Fowler in turn set out to deregulate the broadcasting industry. Under his leadership, the FCC abandoned much of its reliance on rules governing every aspect of broadcast ownership and operation.

Largely as a result of Fowler's efforts, the FCC currently views efficiency and broadcaster discretion as the best ways to serve the

† A.B. 1988, Princeton University; J.D. Candidate 1992, The University of Chicago.

144 Stat 1162, codified at 47 USC $\$ 81$ et seq (1927), repealed by $\S 602$ (a) of the Federal Communications Act of 1934, 48 Stat 1064, 1102, codified at 47 USC $\S 602$ (a) (1988).

348 Stat 1064, codified at 47 USC $\$ 151$ et seq (1988) ("the Act").

347 USC $\$ 303$ (1988).

- President Reagan nominated Fowler as Chairman in early 1981. Fowler remained Chairman until 1987. FCC Chairman Signing Off, 112 Broadcasting 75 (1987). 
public interest. ${ }^{5}$ While the FCC has not abandoned all regulation, it has comprehensively reviewed its policies, and altered many to better serve efficiency or to increase broadcaster discretion. ${ }^{6} \mathrm{Nev}-$ ertheless, the FCC has yet to apply its policies of deregulation or accommodation to two salient aspects of radio and television station financing: its prohibition of security interests in the broadcast license, and its lengthy procedure governing foreclosure. In February 1991, commercial banks and the National Association of Broadcasters asked the FCC to reconsider the prohibition of security interests in the broadcast license. ${ }^{7}$ This Comment focuses on those finance regulations.

Section I explains the FCC's deregulation and accommodation policies. The FCC has stressed its belief that fostering competition in ownership and giving station owners discretion over operations best serves the public interest. In addition, the FCC has long favored accommodating outside laws such as the Bankruptcy Code and the Uniform Commercial Code (UCC). To better serve these general policies, Section II advocates specific changes in the FCC's security interest and foreclosure policies. The first part of the section argues that the FCC should allow creditors to take a security interest in the license as well as in the tangible assets of a broadcast station for two reasons. First, allowing security interests in broadcast licenses best suits the FCC's policy of efficient regulation. Second, it promotes the FCC's longstanding policy of accommodating state and federal laws, since the UCC recognizes security interests in intangible assets like broadcast licenses. The second part of Section II argues that the FCC should adopt the expedited procedure it currently uses only in bankruptcy proceedings, the "two-tier" transfer of control, for foreclosures outside of bankruptcy as well. Adopting this proposal would create more efficient regulation by lowering the station owner's cost of financing. It would also bring FCC policy into line with the policies underlying the Bankruptcy Code by eliminating incentives to force debtors into bankruptcy prematurely. Changes in these rules and procedures would bring financing policies in line with the FCC's otherwise pervasive attempts to deregulate the broadcasting industry and would ultimately also benefit the broadcaster and the public interest.

- See, for example, In re Deregulation of Radio, 84 FCC2d 968, 971 (1981).

- See discussion of policies reviewed and altered in text accompanying notes 25-63.

? Banks Press for Right to Use Licenses of Broadcast Firms as Security for Loans, Wall St J A4 (May 9, 1991). 


\section{FCC Policies}

The FCC's policies of efficient regulation and accommodation pervade many aspects of its regulation. The FCC sees efficient regulation as the way to ensure that broadcasters best serve the public interest. The FCC also takes the accommodation principle seriously, altering longstanding procedures when necessary in order to avoid conflicts with state and federal laws. ${ }^{8}$ This section explains these policies and the value the FCC places on them.

\section{A. Deregulation}

Over the past ten years, the FCC has come to a new understanding of the broadcasting industry. Chairman Mark Fowler arrived at the FCC in 1981 with a new agenda: deregulation. Under his direction, the FCC began relying on market forces-focusing on efficient operations and licensee programming discretion as the best ways to serve the public interest. ${ }^{9}$ This new philosophy created a framework for an ongoing process of removing many existing ownership and operations regulations. This Comment argues that it also provides standards for reviewing broadcast finance regulations and procedures that have thus far evaded the FCC's scrutiny. ${ }^{10}$

\section{Theory behind the FCC's actions.}

In their seminal article, Chairman Mark Fowler and Legal Advisor Dan Brenner advocated deregulation of commercial radio and television. ${ }^{11}$ The authors argued that the FCC can best serve the public by allowing broadcasters to respond to public demand. The Commissioners reasoned that the historic justifications for regulation do not withstand close scrutiny. Scarcity, the primary justification for regulation, ${ }^{12}$ had given way to abundance. In 1934, when the FCC was created, there were fewer than 900 radio stations and (1986).

- See discussion in In re Tender Offers and Proxy Contests, 59 Rad Reg2d 1536, 1554

- See discussion of these policies at text accompanying notes 25-63.

10 This Comment argues that altering regulations in the area of broadcast financing would be consistent with the FCC's decision that deregulation is appropriate and beneficial. Analyzing the merits of deregulation is beyond the scope of this Comment. For criticisms of the FCC's deregulation policy, see William W. Van Alstyne, The Mobius Strip of the First Amendment: Perspectives on Red Lion, 29 SC L Rev 539, 562 (1978).

${ }^{11}$ Mark S. Fowler and Daniel L. Brenner, A Marketplace Approach to Deregulation, 60 Tex L Rev 207, 209-10 (1982).

12 Id at 221. 
no television stations. ${ }^{13}$ As of May 1, 1985, there were 4,785 AM radio stations, 3,771 commercial FM radio stations, and $907 \mathrm{com}$ mercial television stations. ${ }^{14}$ In addition, cable television, low power television, subscription television and broadcast satellites have greatly increased the number of alternative outlets. ${ }^{15}$

Moreover, as Ronald Coase first pointed out in the context of broadcasting licenses in $1959,{ }^{16}$ all resources are scarce. Ideally, a market-based system uses prices to ensure that scarce resources go to those who will make the best use of them. ${ }^{17}$ Thus, Fowler and Brenner argued that scarcity had never justified regulation. Many courts and the FCC eventually rejected the scarcity rationale, ${ }^{18}$ thereby removing the FCC's primary justification for regulation.

In addition to criticizing the historical reasons for extensive regulation, Commissioner Fowler and other advocates of deregulation have cited several advantages to moving toward a free market in broadcasting. Most importantly, Fowler contended that broadcasters are best able to serve the public's true interest. ${ }^{19}$ The FCC had created the regulations without actually providing the service, or, as Fowler explained it, the FCC had second-guessed the business judgment of risk-taking and innovative entrepreneurs. ${ }^{20} \mathrm{In}$ stead, Fowler argued, recognizing the broadcaster's expertise in running a station efficiently and serving the public interest effectively would best accomplish the FCC's mandate. ${ }^{21} \mathrm{He}$ also argued that regulation limiting broadcaster control inhibits innovation and technological development, because broadcasters who do not completely control their positions on the spectrum have fewer in-

15 American Enterprise Institute Legislative Analysis, Broadcast Deregulation 2-3 (AEI, 1985) (an analysis of current proposals before Congress, prepared by the American Enterprise Institute for Public Policy Research with the help of specialists in law, economics, and government).

14 Id.

18 Id.

${ }^{16}$ Ronald H. Coase, The Federal Communications Commission, 2 J L \& Econ 1, 14 (1959).

17 Fowler and Brenner, $60 \mathrm{Tex} \mathrm{L}$ Rev at 221 (cited in note 11).

1s Syracuse Peäce Council v WTVH TV, 2 FCC Rec 5043, 5054-55 (1987) ("[I]n analyzing the appropriate First Amendment standard to be applied to the electronic press, the concept of scarcity-be it spectrum or numerical-is irrelevant."), aff'd, Syracuse Peace Council v FCC, 867 F2d 654 (DC Cir 1989) (FCC's abolition of the fairness doctrine not arbitrary, capricious, or an abuse of discretion). See also In re Deregulation of Radio, 84 FCC2d at 1027-29.

19 Mark S. Fowler, Foreword, 32 Cath U L Rev 523, 524-26 (1983).

20 Id at 527.

21 Id at 527-28. For an example of inefficient second-guessing, see discussion of the FCC's justifications for eliminating the "three year" rule at notes 29-33. 
centives to learn how to maximize value per unit. ${ }^{22}$ In addition, many commentators argued that content regulation violated broadcasters' First Amendment rights. ${ }^{23}$

Fowler believed that the FCC must be willing to self-destruct to the extent necessary to achieve the shift to the marketplace. ${ }^{24}$ However, he and the Commission adopted the more practical approach of dissolving the FCC's control over station owners through an evolutionary process of "unregulation." By unregulation he meant that the FCC would scrutinize every regulation, and eliminate those that did not further the public interest. ${ }^{25}$ As will be shown below, however, the FCC has yet to scrutinize regulations in two key areas of broadcast financing.

\section{The FCC's actions.}

The FCC has taken substantial steps toward deregulation in both station ownership and operation. On the ownership side, the FCC has eliminated so-called "trafficking" rules that limited alienation of licenses..$^{26} \mathrm{It}$ also relaxed multiple ownership restrictions. ${ }^{27}$ On the operations side, the FCC eliminated all content restrictions,

\footnotetext{
23 Fowler, 32 Cath U L Rev at 523, 527 (cited in note 19); Comment, $A$ "Better" Marketplace Approach to Broadcast Regulation, 36 Fed Com L J 27, 32 (1984). Some argue that complete deregulation, and the resulting ownership of a place on the spectrum, would be the best way to create these benefits. Allowing broadcasters to own and freely trade in the spectrum is an argument beyond the scope of this Comment. For discussion of possible property rights systems, see Fowler and Brenner, 60 Tex L Rev at 242 (cited in note 11); Jora R. Minasian, Property Rights in Radiation: An Alternative Approach to Radio Frequency Allocation, 18 J L \& Econ 221 (1975).

2s See, for example, Matthew L. Spitzer, The Constitutionality of Licensing Broadcasters, 64 NYU L Rev 990 (1989) (arguing that broadcast regulations violate the First Amendment and advocating removal of virtually all restrictions). The FCC has eliminated several regulations based in part on its concern that the regulations violated the First Amendment. See Syracuse Peace Council, 2 FCC Rec at 5047-52 (eliminating fairness doctrine), and In re the Revision of Programming and Commercialization Policies, Ascertainment Requirements, and Program Log Requirements for Commercial Television Stations, 98 FCC2d 1076, 1089 (1984) ("In re the Revision of Programming and Commercialization Policies") (deregulating several aspects of television content regulation). The changes proposed by this Comment do not affect content regulation and thus pose no First Amendment problem.

${ }^{34}$ Mark S. Fowler, The Public's Interest, 4 Com \& L 51, 55 (Winter 1982).

${ }^{25}$ Fowler, 32 Cath U L Rev at 579 (cited in note 19), citing Fowler, Broadcast Unregulation in the 1980's, Television Q at 29-30 (Spring 1982).

${ }^{36}$ In re Amendment of Section 73.3597 of the Commission's Rules (Applications for Voluntary Assignments or Transfers of Control), 55 Rad Reg2d 1081 (1982) ("Applications for Voluntary Assignments").

${ }^{27}$ In re Amendment of Section 73.3555 of the Commission's Rules, the Broadcast Multiple Ownership Rules, 4 FCC Rec 1741 (1988) ("Multiple Ownership Rules").
} 
including guidelines for commercials and non-entertainment programming as well as methods for ascertaining community needs. ${ }^{28}$

a) Removal of restraints on alienation. In 1982, the FCC abolished the "three-year" rule, which required a hearing for any attempted assignment or transfer of a broadcasting license where the current holder had operated with the license for less than three years. ${ }^{29}$ The FCC had adopted the three-year rule in 1962, reasoning that an individual who purchased a station for profit would place earning money above serving the public interest. ${ }^{30}$ In its reversal twenty. years later, the FCC explained that profit and service are not mutually exclusive. ${ }^{31}$ The FCC now reasons that, in today's competitive marketplace, a three-year holding requirement would prevent the license from going to its "higher valued use."32 A holding period requires broadcasters to operate stations they no longer want or are unable to operate successfully while preventing willing and able buyers from taking over operations. Because stations that serve best will profit most, the FCC reasons, broadcasters will buy unprofitable stations not serving the public, improve their performance, and increase profits. ${ }^{33}$

The FCC even believes that speculation in broadcast stations serves the public interest. It recognizes that in broadcasting, as in any other business, "people who trade in broadcast properties, rehabilitate ailing stations with new capital and ideas or relieve unwilling licensees of the responsibility of running a station they no longer want" perform important services. ${ }^{34}$ In short, the FCC believes that relying on market forces and allowing broadcasters to decide when to sell their stations best serves the public interest.

b) Relaxation of multiple-ownership restrictions. The FCC's trust in a competitive market and in operating efficiency

\footnotetext{
${ }^{28}$ In re Deregulation of Radio, 84 FCC2d 968, In re the Revision of Programming and Commercialization Policies, 98 FCC2d 1076.

29 Applications for Voluntary Assignments, 52 Rad Reg2d at 1082.

so Id, citing Applications for Voluntary Assignments or Transfers of Control, 32 FCC 689 (1962).

s1 Id at 1082

${ }^{32}$ Id at 1087. The FCC cites changes in the broadcasting industry as a justification for the change in policy. Id at 1086. Since 1962, when the FCC instituted the three year rule, the number of on-air radio stations increased from 3,712 to 9,125 and television stations increased from 603 to 1,059 . Id. In addition, households receive more stations and have available new technology such as cable and video recordings. Id at 1087.

ss Id.

st Id at 1088.
} 
also underlies its decision to relax multiple ownership (or crossownership) restrictions. ${ }^{35}$ In 1989 , the FCC amended the "one-to-amarket" rule that prohibited a party from owning a radio station and a television station in the same market. ${ }^{s 6}$ These amendments create a waiver policy for proposed radio-television combinations provided certain conditions are met. For example, the FCC will look favorably upon waiver applications for multiple ownership in markets where there will be at least thirty individual licensees after allowing the combination, and in situations involving "failed stations."

The FCC based its decision to relax restrictions on multiple ownership on the increased competition that has accompanied the growth in the total number of stations as well as on the economic efficiencies, and service and programming benefits the modification would create. The FCC explained that relaxing the cross-ownership rules would not significantly decrease the diversity of viewpoints represented, reasoning that the huge increase in the number of outlets over the past twenty years would diffuse the potential impact of allowing any one broadcaster to own two licenses in the same area. ${ }^{38}$ Moreover, the comments of current television licensees suggest that station owners do not necessarily adopt the same viewpoint for each of their stations. ${ }^{39}$ Thus, the FCC concluded that allowing more cross-ownership would not significantly affect viewpoint diversity. ${ }^{40}$

3s Multiple Ownership Rules, 4 FCC Rec 1741.

36 Id at 1742. The Commission adopted the "one-to-a-market" rule in the early 1970s. See In re Amendment of Sections 73.35, 73.240, and 73.636 of the Commission Rules Relating to Multiple Ownership of Standard, FM and Television Broadcast Stations, 22 FCC2d 306 (1970) (restricted to owning one AM-FM pair or one television station); In re Amendment of Sections 73.34, 73.240, and 73.636 of the Commission's Rules Relating to Multiple Ownership of Standard, FM, and Television Broadcast Stations, 50 FCC2d 1046 (1975) (cannot own station and a newspaper).

37 Multiple Ownership Rules, 4 FCC Rec at 1750. The "failed station" criterion allows multiple ownership when a station has not operated for a significant amount of time or when one is involved in a bankruptcy proceeding and would not be able to operate without the waiver. Id at 1752 .

sa Id at 1743-44.

39 For example, CBS stated that "in $45 \%$ of the instances in which CBS-owned television and radio stations in the same market made endorsements in electoral races from 19801983, they endorsed opposing candidates." Id at 1744. Similarly, NBC stated that, even among its stations located in the same market, editorial and programming decisions are made independently from other NBC-owned stations, resulting in different editorial and programming decisions between stations. Id.

40 The FCC had also originally intended the prohibition of cross-ownership to foster competition among broadcasters. Id at 1742 . But in its 1988 decision, the FCC concluded that the increased number of stations in each area had decreased the potential for anticompetitive results from relaxing the rules. Id at 1746. 
The FCC argued not only that the original justifications for restrictions on multiple ownership had faded, but also that a relaxation of the rules would bring significant benefits. Specifically, the FCC found that joint ownership often brings significant cost savings resulting from economies of scale. ${ }^{41}$ It believed that such savings to licensees might ultimately create programming benefits in the form of more news, public affairs, and other non-entertainment programming. A National Association of Broadcasters study reported that group-owned stations spent a larger percentage of their budgets on this non-entertainment programming than did independent, stand-alone stations. ${ }^{42}$ In addition, group-owned stations aired more non-entertainment programming than did stand-alone stations. ${ }^{43}$

c) Elimination of content regulations. Although deregulation of ownership was substantial, these changes pale in comparison to the deregulation of operations. Content regulations governing commercials and programming have virtually disappeared for radio and television broadcasters. The FCC justifies this sweeping liberalization by focusing on the benefits produced by giving broadcasters discretion to respond to market forces.

In 1979, the FCC began an inquiry into whether the enormous growth in the broadcast industry had rendered its content regulations of radio obsolete. ${ }^{44}$ The Commission concluded that the increase in the number of broadcast outlets had forced broadcasters to target specific audiences in order to compete. According to the FCC, this change in the broadcasting environment justified the elimination of content guidelines in four major areas: non-entertainment programming, commercialization, ascertainment, and program logs. ${ }^{45}$

With respect to non-entertainment programming, the Commissioners believed that market forces would ensure continued support for non-entertainment programming that satisfied viewer preferences. The FCC wanted to give broadcasters "maximum flexibility to be responsive to issues important to their listeners" with a minimum amount of governmental interference." ${ }^{36}$ An FCC re-

\footnotetext{
11 Id.

$\$ 2$ Id at 1748.

13 Id.

4 In re Deregulation of Radio, 84 FCC2d 968.

45 Id at 969-70.

4 Id at 978.
} 
port stressed the Commissioners' belief that deferring to broadcasters' "good faith discretion" in setting the level of non-entertainment programming would best serve the public interest. ${ }^{47}$

The FCC relied on similar reasoning in eliminating the requirement of a formal hearing for any application that proposed to air more than eighteen commercial minutes per hour of programming. ${ }^{48}$ The FCC reasoned that advertisers, audiences and station owners created a "self-regulating system," thus making FCC regulation appear unnecessarily burdensome. Eliminating the hearing requirement would also increase broadcasters' commercial flexibility and provide audiences with a greater diversity of commercials for consumer products. ${ }^{49}$

Critics raised two significant arguments against deregulation of programming content. First, several commentators feared that station owners would reduce or eliminate non-entertainment programming once the FCC removed its guidelines. ${ }^{50}$ The FCC disagreed. It argued that since the amount of non-entertainment programming actually provided far exceeded the FCC guidelines, the guidelines did not significantly affect the amount of time broadcasters devoted to non-entertainment programming. ${ }^{51}$ In addition, the FCC noted that radio stations devoted the most time to informational programming during the morning and afternoon rush hours-the hours that draw the most listeners and the most advertisers. $^{.2}$ Stations also spent significant amounts of money on live reports and other expensive news-gathering techniques not required by FCC guidelines. ${ }^{53}$ The FCC reasoned from these examples that public demand would ensure continued non-entertainment programming. ${ }^{54}$

Second, commentators expressed concern that stations operating in a deregulated environment would reduce or eliminate pro-

47 Id at 983.

4s Id at 1000, citing FCC Rules § 0.281, 47 CFR § 0.281 (1990).

1 Id at 1004-06.

${ }^{80}$ Id at 1056-57, citing comments by the American Federation of State, City, and Municipal Employees and the U.S. Catholic Conference.

s1 Id at 1057-58, citing studies by the National Association of Broadcasters and the Diocese of Cleveland.

s2 Id at 1058.

ss Id at 1064 .

so Id at 1058-59, 1062-63. The FCC did admit that listeners do not seem to demand public affairs programming. Id at 1064. However, the report cited data showing that as market size increased so did public affairs programming. Id at 1065. The FCC reasoned that a small audience does exist for such programming and that some broadcasters could be expected to respond to this demand if other broadcasters cut back. Id. 
gramming directed toward low income and minority groups..$^{55}$ The FCC responded by explaining that its policies encouraging minority ownership of stations would ensure the continued availability of programming responsive to minority interests. ${ }^{56}$ In addition, the FCC pointed to evidence that the diversity of expressed viewpoints and the types of programming formats increased as the number of stations increased. As competition increased, stations had to appeal to smaller and smaller segments of the community to find a listening audience not already tapped by another station. ${ }^{57}$ Finally, the FCC reasoned that since minorities were becoming an increasingly attractive audience for advertisers, station owners would provide programming aimed at minorities irrespective of FCC guidelines. ${ }^{58}$

In addition to these specific criticisms, several commentators argued that the FCC was abandoning the statutory "public-interest" approach with a marketplace approach. ${ }^{59}$ The FCC disagreed, arguing instead that the public interest can be met through reliance on market forces in the radio market. The FCC construed the public interest standard as providing the "maximum service to the public at the lowest cost and with the least amount of regulation and paperwork."

The FCC followed deregulation of radio content with similar deregulation of television content. In so doing, it emphasized the "importance and viability of market incentives as a means of achieving our regulatory objectives" and its belief that deregulation of programming content would "provide television broadcast-

${ }^{85}$ Id at $1065,1088-89$.

se Id at 1065 .

s7 Id at 1066 .

ss Id at 1067.

so Id at 974.

oo Id at 971. The Supreme Court has interpreted the Act as giving the FCC discretion in deciding how best to serve the public interest. See, for example, FCC $v$ NCCB, 436 US 775, 795 (1978), and NBC v United States, 319 US 190, 218 (1943). More specifically, the courts have held that the FCC may allow market forces to operate if the FCC finds that the free market will best serve the public interest, convenience, and necessity. See, for example, FCC $v$ WNCN Listeners Guild, 450 US 582, 585-86 (1981) (upholding FCC's decision to allow licensees to change their formats as they see fit instead of requiring FCC approval over such changes); Office of Communication of United Church of Christ v FCC, 707 F2d 1413, 1432 (DC Cir 1983) (upholding Report and Order on Deregulation of Radio); Office of Communication of United Church of Christ v FCC, 911 F2d 803, 810 (DC Cir 1990) (upholding FCC's decision to replace requirement that applicants submit detailed information regarding proposed programming with a declaration that they will comply with their public service obligations). 
ers with increased freedom and flexibility in meeting the continuously changing needs of their communities."

Finally, constitutional concerns led the FCC in 1987 to abandon the fairness doctrine, which had required broadcasters to cover controversial issues and to give interested citizens a chance to present conflicting views. ${ }^{62}$

In summary, these changes in ownership and operations regulations reflect the FCC's belief that the marketplace best serves the public interest. Giving broadcasters discretion over station operations and programming means stations will operate more efficiently. These efficiencies in turn may translate into programming that is better tailored to listener demand. ${ }^{63}$ The FCC currently views reliance on market forces, the encouragement of licensee discretion and efficient operations as the best ways of serving the public interest. $^{.4}$ 1077.

1. In re the Revision of Programming and Commercialization Policies, 98 FCC2d at

62 In In re Inquiry into Section 73.1910 of the Commission's Rules and Regulations Concerning the General Fairness Doctrine Obligations of Broadcast Licensees, 102 FCC2d $143,190-92$ (1985), the FCC expressed its belief that the fairness doctrine violated broadcasters' First Amendment rights by chilling speech and requiring the government to act as a censor. The FCC formally abolished the doctrine in Syracuse Peace Council, 2 FCC Rec at 5057-58. For further discussion, see Mark A. Conrad, The Demise of the Fairness Doctrine: A Blow for Citizen Access, 41 Fed Com L J 161 (1989); John J. Hearn, The Demise of the Fairness Doctrine, 56 Geo Wash L Rev 834 (1988).

ss The FCC's reliance on the marketplace and its decision to equate viewer preferences with the public interest is extremely controversial. This Comment takes the FCC's decision to deregulate as a given, and points out that its security interest and foreclosure policies are inconsistent with its new philosophy. Thus, evaluating the merits of deregulation is beyond the scope of this Comment. For critical evaluations, see, for example, Cass R. Sunstein, Preferences and Politics, 20 Phil \& Pub Affairs 3, 28-29 (1991) (arguing that regulation, not reliance on the marketplace and consumer preferences, best serves the public interest); Comment, The FCC and AM Stereo: A Deregulatory Breach of Duty, $133 \mathrm{U} \mathrm{Pa} \mathrm{L} \mathrm{Rev} \mathrm{265,}$ 266 (1984) (arguing that the "FCC's treatment of AM stereo is a paradigmatic example of deregulation that is not in the public interest"); Comment, Deregulating Commercial Television: Will the Marketplace Watch Out for Children?, 34 Am U L Rev 141, 143 (1984) (arguing that the "FCC's decision [to let the market operate instead of establishing] specific regulations over children's programming violates its duty to serve the public interest and does not represent reasoned decisionmaking"); Comment, Radio Deregulation and the Public Interest: Office of Communication of the United Church of Christ v. Federal Communications Commission, 4 Cardozo Arts \& Enter L J 169 (1985) (arguing that deregulation of radio will impede the ability of the public, prospective competitors, and the FCC to challenge a broadcaster's compliance with the public interest mandate).

of In evaluating its regulations, the FCC has not always decided that deregulation best serves the public interest. See, for example, In re Amendment of the Commission's Rules to Allow the Selection from Among Competing Applicants for New AM, FM and Television Stations By Random Selection (Lottery), 5 FCC Rec 4002, 67 Rad Reg2d 1514 (1990) (deciding not to implement a random selection or lottery procedure to select among competing applicants for new AM, FM, and television stations because of concern that reduction in quality of broadcasting licensees and service would outweigh potential efficiency gains); Ap- 
B. Accommodation

While the FCC's deregulation policies focus on the relationship between the broadcast station owner and the FCC, the FCC's accommodation policy focuses on the relationship between FCC policies and state and federal laws. The FCC has a longstanding policy of accommodating state and federal laws when it can do so without infringing on its exclusive authority to make public interest determinations in licensing matters. ${ }^{65}$

For example, the FCC has altered its procedures concerning the sale or assignment of broadcast licenses in order to accommodate federal bankruptcy law. ${ }^{86}$ Usually, the FCC will not approve any assignment requested by an owner who cannot meet the FCC's renewal qualifications. ${ }^{67}$ But in order to reconcile its policies with federal bankruptcy policies, the FCC is less strict when a bankruptcy trustee requests an assignment. LaRose $v F C C^{88}$ indicates how the FCC has made such an accommodation. In LaRose, the FCC considered the bankruptcy trustee's request for assignment of a license, even though the trustee represented a station owner who could not have made the same request in a non-bankruptcy setting. ${ }^{69}$ The District of Columbia Circuit required the Commission to "approve the sale and assignment of the bankrupt's license when the transaction will not unduly interfere with the FCC mandate to insure that broadcast licenses are used and transferred consistently with the Communications Act." "70 The FCC was to provide

plications for Voluntary Assignments, 55 Rad Reg2d at 1089-90 (reducing, but not eliminating, the holding period for permits to build a new station in order to "maintain the integrity of the Commission's licensing processes and effectuate the intent of Sections 301 and 304 of the Act.").

os The FCC does refuse to accommodate federal or state law when it finds that it cannot defer without acting in derogation of its responsibilities under the Act. See, for example, In re Merkley, 94 FCC2d 829, 839 (1983) (refusing to accommodate a state court's decision to uphold a sales agreement that contained a prohibited reversionary interest).

os See, for example, In re Application of Second Thursday Corp., 22 FCC2d 515 (1970).

67 Instead, the license reverts back to the FCC at the end of the station owner's term, and the FCC assigns the license so that the owner receives none of the benefits from the assignment.

${ }^{63} 494$ F2d 1145 (DC Cir 1974).

69 Id at 1148. In this case, the D.C. Circuit found that the FCC had not followed its own accommodation policy. The court ordered the FCC to consider the trustee's second request for assignment even though it had rejected the first proposed assignment for failing to satisfy the FCC's requirements. The FCC's mistake on the facts in this case does not detract from the general point that it should and does accommodate federal bankruptcy policy. The case also shows the courts' willingness to force the FCC to accommodate federal policies when it is feasible for the FCC to do so.

70 Id. See also In Re Fugazy Express Inc., 114 Bankr 865, 874 (S D NY 1990) (citing LaRose with approval); In re Smith, 94 Bankr 220, 221 (M D Ga 1988) (same); In re Merk- 
this accommodation "in recognition of the public interest in protecting innocent creditors." 11

In another context, the accommodation policy motivated the FCC to change an entire set of regulations. In 1986, the FCC created an exception to its usual transfer-of-control application process for stations involved in tender offers. Section 310 (d) of the Communications Act requires FCC approval prior to any transfer of control. Originally, anyone who wanted to use a tender offer to take control of a broadcasting company would have to submit a long-form transfer-of-control application. However, review of the transfer-of-control application is a lengthy process that conflicts with the federal securities policies against unwarranted regulatory delay and governmental bias. ${ }^{72}$ The FCC determined that in order to accommodate federal securities laws regarding tender offers, it would allow applicants to use an expedited process.

The FCC articulated four primary objectives in changing the policy: complying with the Communications Act; avoiding unnecessary delay; ensuring FCC neutrality; and accommodating state and federal policy. ${ }^{73}$ To resolve the conflict between these large potential delays and the policies of eliminating unwarranted regulatory delay and of ensuring government neutrality, the FCC formulated an alternative two-tier procedure that involved a grant of special

ley, 94 FCC2d 829,837 (1983) (noting that purpose of this policy "is to permit trustees or receivers to fulfill the obligations of their appointment [to dispose of the station's assets], and, in some cases, to assure the continued operation of the licensed facility").

"1 LaRose, 494 F2d at 1148.

72 In re Tender Offers, 59 Rad Reg2d at 1558-62. As the report explains, "Commission consideration of the merits of the transfer under the long form process involves a myriad of time-consuming steps." Id at $1550 \mathrm{n} 66$. First, interested parties have at least thirty days to petition the FCC to deny the application. 47 USC § 309(d)(1) (1988). The applicant has ten days after the petition has been filed to file its opposition to the petition, and the petitioner then has five days to reply. 47 CFR $\$ \S 1.45(\mathrm{a}), 1.4(\mathrm{~g})(1990)$. If either of the parties is served by mail, the party has an additional three days added to the time to respond. 47 CFR $\S 1.4(\mathrm{~h})(\mathrm{i})$ (1990). If no contested issues of fact remain when the parties have completed these exchanges, the staff analyzes the record and makes a recommendation to the Commissioners. The Commissioners then render a decision.

However, if "substantial and material" questions of fact remain, the Act requires a hearing before the Commission. 47 USC § 309(e) (Supp 1991). This entails a "potentially time-consuming discovery process ...., the direct testimony of witnesses and cross examination." In re Tender Offers, 59 Rad Reg2d at $1550 \mathrm{n} 66$. Certain issues arising during the hearing may trigger an interlocutory appeal to the Review Board. 47 CFR § 1.301 (1990). Once the Review Board rules and the hearing concludes, an administrative law judge renders a decision. The parties have a right to file exceptions with the Review Board within 30 days of public release of the judge's decision. After the Review Board proceedings conclude, parties may file an application for review with the Commissioners. In re Tender Offers, 59 Rad Reg2d at $1550 \mathrm{n} 66$.

${ }^{73}$ In re Tender Offers, 59 Rad Reg2d at 1539-40. 
temporary authority to a trustee while the FCC reviewed the longform application. ${ }^{74}$

While the FCC considers the long-form application, the trustee has a limited ability to participate in the management and operations of the company. The trustee must safeguard the corporate assets. ${ }^{75} \mathrm{He}$ must "protect the buyer from unwarranted or imprudent actions by the existing Board of management, such as voting themselves overly generous benefits or wasting corporate assets." The trustee must also ensure continuity of broadcast operations. $\mathrm{He}$ may replace officers, directors or employees who have either resigned or who are not acting consistently with the trustee's obligations. ${ }^{77}$

The FCC based its authority to implement this two-tier procedure on $\S 309$ (f) of the Communications Act. ${ }^{78}$ This section empowers the FCC to grant special temporary authority if it determines that " "extraordinary circumstances exist requiring temporary operations in public interest,' and [it] further determine(s) that 'delay in the institution . . . of temporary operations would seriously prejudice the public interest.."79 The FCC reasoned that the need to accommodate federal securities policies presents "an extraordinary circumstance which warrants the use of special procedures." ${ }^{80}$ Because $\S 309(f)$ gives the FCC authority to postpone the requirement of the long-form application, creating an exception to the usual procedure allowed the FCC to follow its statutory mandate while accommodating federal securities policies. The FCC felt accommodation was important enough to alter its own policies.

These two policies, deregulation and accommodation, represent the FCC's framework for regulating in the public interest. Although the FCC has implemented these policies in many areas of ownership and operation, it has not implemented them in the area of broadcast finance. The next section examines how the FCC's prohibition on security interests and its procedures for foreclosure frustrate its deregulation and accommodation policies. In each of these areas, the Comment explains how changes in these finance

24 Id at 1562-63. Section 309(f) of the Communications Act gives the FCC the ability to grant special temporary authority.

${ }^{25}$ In re Tender Offers, 59 Rad Reg2d at 1582.

${ }^{26}$ Id.

77 Id at 1583.

7s 47 USC $\S 309(f)$ (1988).

${ }^{79}$ In re Tender Offers, 59 Rad Reg2d at 1569-70, citing 47 USC § 309(f) (1982).

so Id at 1570. 
regulations will benefit the FCC, the licensee, the creditors, and the public.

\section{FCC's Broadcast Financing Policies}

In two areas of financing regulation, the FCC's current methods of furthering the public interest conflict with the efficiency and accommodation policies described in Section I. First, the FCC clings to an inefficient prohibition on security interests in licenses that rests on justifications abandoned by the FCC in its recent deregulation of other areas. This prohibition is also inconsistent with a provision of the Uniform Commercial Code that allows security interests in intangibles, and thus frustrates the FCC's accommodation policy.

Similarly, the FCC's procedure for dealing with a creditor's foreclosure on the assets of a station conflicts with its policy of regulating efficiently. This policy not only creates incentives to enter bankruptcy when it may not benefit all parties to do so, but also violates an underlying tenet of the Bankruptcy Code by creating different substantive rights for creditors in bankruptcy. This Section argues that these internal inconsistencies in FCC regulatory policy justify change.

\section{A. FCC Prohibition on Security Interests in Broadcast Licenses}

Broadcast stations operate in an active and competitive market, with about ten percent of all radio stations changing hands each year. ${ }^{81}$ The value of a station in large part derives from the ability to use a part of the spectrum, an intangible asset. The station's physical assets generally constitute a very small part of the station's overall value. Notably, the higher the selling price of the station is, the greater the percentage of intangible assets in the total station value. Specifically, the National Association of Broadcasters estimates that the intangible assets would represent onethird of the total value of a radio station sold for three hundred thousand dollars, while they would represent two-thirds of the value of a station sold for three million dollars. ${ }^{82}$ As these estimates show, the price of a station far exceeds the value of the station's tangible assets. Accordingly, potential purchasers who cannot finance the acquisition on their own must borrow far more

\footnotetext{
81 National Association of Broadcasters, Broadcast Lending: $A$ Lender's Guide to the Radio Industry 11 (NAB Radio, 1980).

s2 Id.
} 
money than the tangible assets are worth in order to buy the station.

Lenders consider many factors when deciding to make a loan. Security is high on the list of relevant factors. ${ }^{83}$ Lenders like to hold collateral equal to or greater than the value of the loan. Of course, most borrowers, like station owners, could not make any money to repay the loan if the bank physically kept the business's equipment as collateral. Article 9 of the UCC solves this problem by allowing the creditor to take a security interest in the borrower's property. A security interest gives the lender two kinds of rights. First, the lender gains property rights, meaning that under certain circumstances the lender can repossess the property or go to court to have the sheriff repossess and sell the property. ${ }^{84}$ The lender also gains priority rights for collection on the property in the event of a default. ${ }^{85}$

Lenders that take security interests in a debtor's assets are only protected up to the value of those assets. Thus, lenders that use security interests want to be fully secured; that is, they want the value of the assets in which they have security interests to equal or exceed the amount of the loan. With broadcast station lending, this would mean that a lender that provides a substantial amount of the purchase price would want a security interest in the intangible license as well as the station's tangible assets.

While the UCC permits security interests in intangible property such as licenses, the FCC does not. This increases the costs of borrowing. Moreover, the FCC's refusal to recognize security interests in intangibles, in direct contrast to the UCC, conflicts with the FCC's longstanding policy of accommodation. The following subsections explain how allowing creditors to take a security interest in both the station's tangible and intangible assets would benefit the FCC, the licensee, and the public. ${ }^{86}$

1. The FCC's current position on security interests.

The FCC has held unequivocally that a broadcast license is not subject to a lien. ${ }^{87}$ It has advanced two reasons for its position.

ss Id at 13.

84 UCC \& 9-203 (ALI, 1987).

so UCC $\S \$ 9-301$ and 9-312 (ALI, 1987).

B8 The arguments in this Comment would support both the policies of allowing a security interest in the license alone and of requiring the lender to take a security interest in both the tangible and the intangible assets. A discussion of the relative merits of those policies, however, is beyond the scope of this Comment.

87 See, for example, In re Merkley, 94 FCC2d 829; In re Radio KDAN, Inc., 13 Rad Reg2d 100 (1968); Stephens Industries, Inc. v McClung, 789 F2d 386 (6th Cir 1986). 
First, the FCC interprets several sections of the Communications Act to mean that the license cannot be subject to "a reversionary interest, a mortgage, a lien, a pledge or any other form of security." 88 The first such section is 47 USC $\S 301$ (1988), which states that the Act's purpose is "to provide for the use of [radio transmissions] channels, but not the ownership thereof . . ., by persons for limited periods of time, under licenses granted by Federal authority ...." The second is 47 USC $\S 304$ (1988), which requires an applicant for a license to have signed a "waiver of any claim to the use of any particular frequency" based on previous use of the frequency. The third is 47 USC $\S 309(\mathrm{~h})$ (1988), requiring a station license to state that it "shall not vest in the licensee any right to operate the station nor any right in the use of the frequencies designated by the license beyond the term" of the license. The final provision is 47 USC $\S 310$ (d) (1988), which requires Commission approval prior to the transfer, assignment or disposal of rights in a construction permit or station license.

Since the licensee only uses the license subject to FCC control, the Commission reasons that the licensee has no property right in the license. ${ }^{89} \mathrm{~A}$ licensee who does not own a license should not be able to retain any right to regain his ownership if the new owner defaults on a provision in the sales agreement. In addition, a reversionary interest or a security interest would limit the field of possible successors to the license. ${ }^{80}$

The second reason the FCC advances for its present position is that it feared that encumbrances on a broadcast license would "endanger[] the independence of the licensee who is and should be at all times responsible for and accountable to the Commission in the exercise of the broadcasting trust." "In short, the FCC fears that allowing security interests would give creditors influence over station operations. ${ }^{92}$

so In re Commission Policy Regarding the Advancement of Minority Ownership in Broadcasting, 92 FCC2d 849, 860 (1982), citing Churchill Tabernacle v FCC, 160 F2d 244 (DC Cir 1947) (respecting FCC's decision to prohibit security interests); In re The Yankee Network, Inc., 13 FCC 1014 (1949); In re Radio KDAN, Inc., 13 Rad Reg2d 100; In re Bonanza Broadcasting Corp., 11 Rad Reg2d 1072 (1967). Most recently, the FCC reiterated its views in In re Omega Cellular Partners, 5 FCC Rec 7624 (1990).

so MG-TV Broadcasting Co. v FCC, 408 F2d 1257, $1264 \mathrm{n} 21$ (DC Cir 1968).

'0 In re The Yankee Network, Inc., $13 \mathrm{FCC}$ at 1020.

-1 In re Radio KDAN, Inc., 13 Rad Reg2d at 102.

92 Evaluating whether the FCC's interpretation of the Act is the best interpretation or even a plausible one is beyond the scope of this Comment. The Comment argues that agency consistency (without any reference to outside policy or statutory construction argu- 
2. The conflict with the FCC's deregulation policy.

a) Licensee discretion. The FCC has abandoned its justifications for prohibiting security interests. In deregulating ownership and operations, the FCC increased broadcast station owner discretion to better serve the public interest. Giving discretion to station owners to choose financing options supports recognition of security interests rather than their prohibition.

Moreover, the FCC negates its voiced concern about creditor control by accepting substitute means of creating security, like stock pledge agreements coupled with negative pledge clauses. ${ }^{93}$ Lenders who rely on these types of security must monitor their debtors more intensively than lenders who are fully secured. And although lenders have no formal control or input into station operations, they often have increasing amounts of de facto control as the licensee moves closer to default. Once the debtor breaches a loan covenant, for example, the lender has the power to file a transfer of control application and begin the process of taking control from the licensee. At this stage, negotiation often occurs and a licensee who wants to keep her station has strong pressure to listen to her lender's suggestions. Although the FCC prohibits such input by third parties, it does occur. ${ }^{94}$ Thus, allowing any lending to broadcast stations creates the evils the FCC cites as its justification for prohibiting security interests. Since security interest agreements can specify that the lender will not have any input into operations, allowing this method of financing does not create any more lender control than current financing methods create.

The FCC's acceptance of stock pledge agreements also negates any argument that the Communications Act itself prohibits security interests. In essence, the statutory provisions the FCC relied on in banning security interests ${ }^{95}$ state that a licensee only has the rights given to it by the FCC. Since the FCC allows stock pledge agreements, it must believe that these agreements do not violate the Communications Act. Like a stock pledge, a security interest in

ments) requires changes in security interest and foreclosure policy. Thus, it starts with the FCC's original interpretation of the Act, pointing out that the FCC has since abandoned its own reasons for this interpretation.

${ }^{\text {93 }}$ See text accompanying notes $96-98$ for discussion of proxies that lenders currently use to get around the prohibition of security interests.

or Interview with Jeff Kilrea, Vice President of Greyhound Financial of Chicago, IL (October 12, 1990) (notes on file with U Chi L Rev). Kilrea coordinates financing for advertising-driven media.

${ }^{95}$ See text accompanying note 88 . 
a license would be limited to the rights given to the licensee by the FCC. A security interest does not expand the rights of a licensee or a lender any more than does a stock pledge agreement. Thus, the language of the Communications Act does not compel the FCC's prohibition on security interests.

b) Efficiency. Substitute security arrangements such as stock pledge agreements coupled with negative pledge clauses are more costly to both lenders and broadcasters than are fully-secured loans. Efficiency therefore dictates that the FCC allow license holders to give security interests in those licenses instead of forcing them to use costlier mechanisms. The following paragraphs explain why these substitute security agreements are inefficient and costly.

Lenders combine two substitute security methods to achieve the property and priority rights denied them by the FCC's prohibition of security interests in the intangible assets of a broadcasting station. ${ }^{96}$ Typically, in providing financing to a broadcasting station, a lender will take a security interest in the tangible assets and a stock pledge agreement on all of the stock of the company. ${ }^{97}$ The security interest gives the lender priority and property rights to the station's equipment. The stock pledge agreement gives the creditor constructive custody or control of the station's stock as security for the debt. If the debtor defaults, he must sign over ownership of the stock to the lender, thus giving the lender control over station operation upon default.

The lender often will also include negative covenants in the loan agreement in an attempt to preserve priority. These negative covenants restrict the debtor's ability to borrow in the future. They may bar all future debt or they may require the debtor to maintain a certain ratio between current earnings and fixed charges. This latter type of clause has the effect of allowing trade credit without allowing significant future financing. The creditor can enforce the restrictive covenant by making its violation an act of default. A negative covenant is a proxy for the priority rights created by a security interest, since a lender which is the only one

os Lenders can and do take security interests in the station's tangible assets to protect their priority and property rights in those assets. However, as explained above, see notes 8182 and accompanying text, the tangible assets make up only a small fraction of the total station value.

97 See Jack Whitley, A Primer on Commercial Transactions Under the Communications Act, 72 Ill Bar J 26, 30 (Sep 1983). 
in line for the debtor's assets comes first in collecting on those assets. ${ }^{98}$

These alternative financing methods currently used by lenders provide inferior property and priority rights to those created by a security interest. Because the tangible assets of a station constitute only a small percentage of the station's value, having the right to foreclose on these assets alone does not give a lender much comfort. So lenders take stock pledge agreements to gain control over a station in default. However, a transfer of more than fifty percent of the station's stock is considered a transfer of control, which requires the lender to file a long-form transfer of control application. While the lender waits for FCC approval, it has no say in the station's operation and thus cannot protect the assets that provide its source of repayment. ${ }^{99}$ Likewise, the negative pledge agreement provides little protection to the creditor. While the clause resembles a security interest because it provides that no other creditor can share in the debtor's assets, ${ }^{100}$ courts have almost uniformly held that a negative pledge agreement does not create a security interest. ${ }^{101}$ Thus, if the courts will not enforce negative pledge agreements, ${ }^{102}$ later lenders will share pro rata with the original

98 Alan Schwartz, A Theory of Loan Priorities, $18 \mathrm{~J}$ Legal Stud 209, 217 (1989).

98 See Section II.B. for the argument that the FCC should change its foreclosure procedures to eliminate the inefficiencies created by the delay involved in a long form transfer of control.

${ }^{100}$ Thomas C. Mitchell, The Negative Pledge Clause and The Classification of Financing Devices, $60 \mathrm{Am}$ Bankr L J 153, 156 (1986).

${ }_{102}$ See, for example, In re Friese, 28 Bankr 953 (D Conn 1983) (will not imply creation of lien from a negative clause); Equitable Trust Co. v Imbesi, $287 \mathrm{Md} 249,412$ A2d 96 (1980) (same); Manatee Federal Savings \& Loan Association v Pace, 378 S2d 95 (Fla Ct App 1979) (same); Palmeri v Allen, 30 Conn Supp 56, 299 A2d 552 (1972) (parties who want to create security interest should use UCC form); Equitable Trust Co., 275 Md at 249, 412 A2d at 96 (same); Weaver v Tri City Credit Bureau, 27 Ariz App 640, 557 P2d 1072 (1976) (negative pledge agreements could be used to take advantage of unsophisticated borrowers); Browne v San Luis Obispo National Bank, 462 F2d 129 (9th Cir 1972) (same). In Coast Bank v Minderhout, 61 Cal2d 311, 38 Cal Rptr 505, 392 P2d 265 (1964), the California Supreme Court became the first and only court to find that a negative pledge agreement gave the creditor a priority right. However, the court subsequently backed away from its holding and subsequent lower court cases in California have come out both ways with similar facts. Compare Kaiser Industries v Taylor, 17 Cal App3d, 94 Cal Rptr 773 (1971) (finding security interest in agreement not to encumber or transfer), with Orange County Teachers Credit Union v Peppard, 21 Cal App3d 448, 98 Cal Rptr 533 (1971) (refusing to find a security interest in such an agreement). No other state court has followed the original California Supreme Court holding, and several have specifically declined to follow it. See Weaver v Tri City Credit Bureau, 557 P2d at 1076 (calling court's reasoning "weak").

${ }^{102}$ The lender therefore cannot stop the debtor from borrowing money from other creditors who lend money without knowledge of the pledge agreement. Schwartz, $18 \mathrm{~J}$ Legal Stud at 210, 218 (cited in note 98). If the later lender knows of the negative pledge clause, the original lender may be able to sue for inducing breach of contract, but such suits are rarely filed since it is so difficult to prove inducement. Id at $210 \mathrm{n} 5$. 
lender if the debtor defaults. ${ }^{103} \mathrm{~A}$ creditor that must share in the division of assets has a smaller chance of repayment than a creditor who has priority.

The inferiority of these alternative methods of securing loans means that rational creditors which lend to broadcast stations will charge the licensee more interest than they would charge if they could ensure priority by taking a security interest directly. ${ }^{104}$ This increased cost to the licensee conflicts with the FCC's new emphasis on efficient, least-cost regulation. Recognizing security interests in the tangible and intangible assets of a station would result in savings to the licensee, and allow her better to serve the "public convenience, interest, or necessity."

3. The conflict with the FCC's accommodation policy.

Allowing security interests in licenses would also better serve the FCC's accommodation policy. The UCC generally recognizes security interests in intangible property, which would include broadcast licenses. ${ }^{105}$ The UCC also recognizes, however, that the FCC policy prohibiting security interests trumps UCC policy. ${ }^{106}$ But as the previous sections illustrate, the FCC's new emphasis on broadcaster discretion and regulatory efficiency has cut away the underlying justifications for its policy. In doing so, the FCC has cleared the way for accommodation.

a) UCC treatment of security interests. Under Article 9 of the Uniform Commercial Code, parties may create a security interest in "personal property or fixtures" whenever it is their intent to do so.107 "Personal property or fixtures" is defined to include "goods, documents, instruments, general intangibles, chattel paper or accounts." 108 "General Intangibles," in turn, is defined to mean "any personal property (including things in action) other than

108 Id.

104 See Thomas H. Jackson, Bankruptcy, Non-Bankruptcy Entitlements, and the Creditors' Bargain, 91 Yale L J 857, 875 (1982). Professor Jackson makes the point that lenders who know of increased risk of undercompensation if default occurs will charge the debtor for this risk when making the loan. Although he is discussing secured credit, the point applies equally well to lenders trying to create a security interest with a negative pledge agreement.

108 UCC \$§ 9-102(1)(a), 9-106 (ALI, 1987).

208 UCC \& 9-104(a) (ALI, 1987).

107 Official Comment to UCC \& 9-102(1)(a). Forty-nine states have incorporated some part of the UCC into state law. Article 9 of the UCC has been adopted by forty-six states. James J. White and Robert S. Summers, Uniform Commercial Code (West, 3d ed 1988).

${ }^{108}$ UCC \& 9-102(1)(a). 
goods, accounts, chattel paper, documents, instruments, and money."109 The Official Comment to Article 9 emphasizes the broad scope of the definition, indicating that it includes "miscellaneous types of contractual rights and other personal property which are used or may become customarily used as commercial security."110

Given the UCC's broad definition of "property," most courts have recognized that creditors can take a security interest in a government license, notwithstanding the control retained by the government over final approval of any transfer of the license. ${ }^{111}$ The courts reason that the government's ability to withhold consent to a transfer of a license does not negate the license's character as transferable property of value, and therefore does not preclude the attachment of a valid security interest in the license. For example, in Rainbo Express, Inc. $v$ National Acceptance Co. of Chicago, ${ }^{112}$ the court upheld the validity of a chattel mortgage as against the debtor's "operating rights" under a Certificate of Public Convenience and Necessity issued by the Interstate Commerce Commission (ICC). The bankruptcy trustee had argued that the Certificate represented a mere permit of a personal nature, emphasizing ICC regulations that provided that no transfer of operating rights could be effective without prior ICC approval. ${ }^{113}$ The court responded that the Certificate represented a property interest to which a lien could attach. While the transfer of the operating rights was subject to the contingency of governmental approval, the rights themselves remained valuable in any event and were transferable once the contingencies were satisfied. ${ }^{114}$ Rainbo Express is but one example of this construction of the UCC.

b) The conflict between the UCC and FCC policy. The UCC and the courts recognize that the amenability of a governmental license to a security interest depends not only on transferability but also on the statute or regulation that creates the license

${ }^{109}$ UCC \& 9-106.

${ }^{210}$ Official Comment to UCC \& 9-106.

${ }^{111}$ See, for example, In re O'Neill's Shannon Village, 750 F2d 679, 682 (8th Cir 1984) (South Dakota liquor license); Bogus v American National Bank of Cheyenne, Wyoming, 401 F2d 458, 461 (11th Cir 1968) (Wyoming liquor license); First Pennsylvania Bank v Wildwood Clam Co., Inc, 535 F Supp 266, 268 (E D Pa 1982) (Pennsylvania commercial clamming license).

112179 F2d 1 (7th Cir 1950).

113 Id at 3.

314 Id at 5. 
rights in the first instance. ${ }^{115}$ The rationale underlying this rule is that the UCC provides for the attachment and enforceability of security interests with respect to "collateral," which is defined as "the property subject to a security interest."116 Thus, when state or federal law expressly provides that certain licenses created thereunder are not properly subject to security interests, courts have held those licenses to be outside the scope of Article 9's definition of property. ${ }^{117}$

Since the Communications Act, as federal law, preempts the UCC where the two conflict, any inconsistency between Article 9's definition of "property" and the FCC's ban on the encumbrance of broadcast licenses must be resolved in favor of the FCC. ${ }^{118}$ The courts that have considered the validity of a security interest taken in an FCC broadcasting license have taken the FCC's pronouncements at face value and have held the security interest invalid. ${ }^{110}$ However, as explained above, the FCC itself has abandoned its reasons for prohibiting security interests. Since the FCC itself has rejected the rationale underlying the conflicting rules, its policy of accommodating state law supports changing them.

Allowing lenders to take a security interest in a station's tangible and intangible assets would reconcile this aspect of finance regulation with the FCC's general policies of deregulation and accommodation. The next section explains how these same arguments

12 UCC § 9-104(a) states that Article 9 does not apply "to a security interest subject to any statute of the United States, to the extent that such statute governs the rights of parties to and third parties affected by transactions in particular types of property ...." Notably, the UCC does not suggest that it is better for a federal agency to rely on the UCC rather than to create its own scheme. Thus, one could argue that the FCC could accommodate the UCC by creating its own scheme to fall within § 9-104(a). An analogy to the FCC's treatment of state contract rules may be helpful in understanding this point. State contract rules (like the UCC) do not suggest that it is better for a federal agency to rely on those rules rather than to bypass them by crafting specific contractual terms. Thus, the argument would go, if the FCC creates its own contract rules it in fact "accommodates" state contract law. The FCC, however, takes a broader view of accommodation: it rejected the analysis described above, instead deferring to state contract rules. See In re Arecibo Radio Corp., 101 FCC2d 545 (1985) (accepting state court judge's decision to remedy licensee's breach of contract by reassigning license to previous licensee without FCC approval). By analogy then, it is consistent to assume that the FCC's own views of accommodation would "require" it to rely on UCC background rules, not merely to adopt its own scheme.

116 UCC \& 9-105(1)(c) (ALI, 1987).

${ }^{127}$ See, for example, 21 West Lancaster Corp. $v$ Main Line Restaurant, Inc., 790 F2d 354 (3d Cir 1986) (holding that federal tax lien against Pennsylvania liquor license defeated creditor's prior lien, since latter's security interest in the license never attached under state law).

118 UCC \& 9-104(a).

11 See, for example, Stephens Industries, 789 F2d 386. 
support changes in foreclosure policy, another aspect of finance regulation.

\section{B. FCC Foreclosure Procedures}

Creditors that lend to a broadcast licensee must comply with FCC regulations when the licensee defaults. The FCC has one set of procedures for licensees that default outside of bankruptcy and another, shorter set of procedures for licensees that enter bankruptcy. The non-bankruptcy procedure involves a longer wait and increased uncertainty than does the bankruptcy procedure. Since creditors see time and risk as money, the long-form procedure used outside of bankruptcy conflicts with the FCC's longstanding policy of regulating stations at the cheapest cost to the licensee. In addition, having separate procedures inside and outside of bankruptcy runs counter to the policies underlying the Bankruptcy Code and creates distorted incentives that may damage the ability of all parties to recoup as much of their investment as possible upon default. Thus, extending the current bankruptcy procedure to all cases involving licensee default would best serve the FCC's regulatory philosophy, federal bankruptcy policy, and the licensee's and the creditors' interests.

\section{Current procedures.}

A creditor of a broadcast station that gains the legal right to foreclose on a station's assets or stock has two options: to foreclose outside of bankruptcy or to force the debtor into bankruptcy. ${ }^{120}$ If a creditor chooses the first option, it will enforce the stock pledge agreement by demanding that the debtor endorse the pledged stock to her. ${ }^{121}$ Upon endorsement, the creditor gains control over the broadcast station's operations and can use this control to recoup its investment.

Under FCC regulations this transfer of stock constitutes a transfer of control. ${ }^{122}$ Section 310 (d) of the Communications Act requires prior FCC approval for any such transfer, ${ }^{123}$ so a creditor

\footnotetext{
${ }^{120}$ See II.A above for a discussion of financing options creditors currently use when lending to broadcast stations. These options give the creditor rights to the stock of the company or to certain assets in the company upon default.

121 Of course this assumes that the station owner does not challenge the validity of the negative pledge agreement, which the courts do not generally uphold. See text at notes 99 108.

${ }^{222} 47$ CFR § 73.3555 (1990).

${ }^{123} 47$ USC $\S 310$ (d) (Supp 1991).
} 
that wishes to take control of the station's stock must file a longform transfer-of-control application and must submit to a thirtyday minimum public notice period. Moreover, FCC approval is itself a lengthy process. ${ }^{124}$ In addition, the FCC may deny the application and assign the station to another interested party, giving the creditor no control over the sale price and thus the amount of money available to pay off the licensee's creditors. Further, the creditor would have to wait until the FCC found a suitable assignee before receiving payment on the debt.

In contrast, the creditor can choose to force the debtor into bankruptcy by filing an involuntary petition. ${ }^{25}$ The debtor can either reorganize and make arrangements to pay off its creditors under Chapter 11 or it can liquidate the business under Chapter 7. ${ }^{126}$ Chapter 7 liquidation mirrors foreclosure outside of bankruptcy since it involves selling the business and paying off the creditors to the extent possible with the proceeds. Chapter 11 bankruptcy, by contrast, is very attractive to creditors.

The Communications Act, $\S 309$ (c)(2)(B), allows an exception to the long-form transfer-of-control process for stations in bankruptcy. Under this provision, the FCC uses a two-tier procedure in which the trustee, debtor in possession, or receiver appointed by the court ${ }^{127}$ files both a short-form and a long-form application. The FCC reviews the short-form application on an expedited basis to decide whether to grant temporary authority to operate the station. ${ }^{128}$ The FCC then considers the long-form application prior to allowing the sale of the station. ${ }^{129}$ The benefit of the bankruptcy procedure is that the trustee may participate in the management and operations of the company while the FCC considers the longform application. The FCC analogized to $\S 309(\mathrm{c})(2)(\mathrm{B})$ and relied on $\S 309(f)$ in implementing the two-tier procedures for transfers of control in tender offers. For the reasons outlined below, this

\footnotetext{
126 The FCC does not keep statistics on the length of time it takes to complete a longform transfer of control application. However, as discussed above, see note 72, the statutory requirements create a lengthy process.

${ }^{125}$ Under 11 USC § 303(b)(2) (Supp 1991) of the Bankruptcy Code; one substantial creditor may force a debtor with fewer than twelve creditors into bankruptcy.

${ }^{228} 11$ USC § 109 (Supp 1991).

${ }_{127}$ See In re D. H. Overmyer Telecasting Co., 94 FCC2d 117, 125 (1983) (no distinction between trustee, debtor in possession and receiver for purposes of FCC procedures).

12847 USC \& 309 (c)(2)(B)(1988). The FCC reviews the short-form application within 30-45 days. Telephone interview with Glen Greisman, Esq., Audio Services Division, FM Branch of the FCC (Feb 27, 1991) (notes on file with U Chi L Rev).

${ }^{229}$ In re Tender Offers, 59 Rad Reg2d at 1581 n 202. See text accompanying notes 7980 for discussion of the FCC's reliance on $\S 309$ (f) in the context of tender offers.
} 
Comment proposes that the FCC rely on $\S 309$ (f) to extend the two-tier procedures to foreclosures outside of bankruptcy as well.

2. The conflicts with the FCC's deregulation policy.

In addition to meeting the requirements of the Communications Act and allowing the FCC to accommodate bankruptcy laws, the exception to the long-form transfer of control procedure used in bankruptcy is an efficient means of dealing with creditors of a station in financial distress. As this section will explain, expanding this procedure to foreclosures outside of bankruptcy would further the FCC's goal of regulating efficiently in order to best serve the public interest. The long-form transfer of control process frustrates the FCC's policy of efficient regulation by increasing the cost of borrowing money. Naturally, the licensee must pay interest when he borrows money. One of the primary determinants of the interest rate a debtor pays is the riskiness of the loan. Basic economic theory instructs that lenders increase the rate of interest charged as the chances of repayment decrease. ${ }^{130}$ Since money received today is worth more to a lender than the same amount of money received tomorrow, the cost of borrowing increases as the time period over which the lender expects to be repaid increases. ${ }^{131}$ The long-form transfer of control process both decreases the chances of repayment and increases the time the creditor must wait for that repayment. Moreover, while the FCC considers the long-form application the creditor cannot influence corporate decisions. Current managers did not operate the station profitably before foreclosure, and may be wasting the value of the license by operating inefficiently during the months of FCC review. ${ }^{\mathbf{1 3 2}}$ In addition, if the FCC denies the application and finds its own assignee for the license, it does not have the incentives to search for a price that would cover the amount of debt owed the creditor.

In contrast, the creditor of a station in bankruptcy can install a trustee to watch over the corporate assets while the creditor searches for an assignee for the station. The creditor knows with certainty that she will be able to protect the assets available for repayment and, through the trustee, ensure that a suitable as-

1so S. Charles Maurice, Owen R. Phillips, C.E. Ferguson, Economic Analysis (Richard D. Irwin, 4th ed 1982).

131 Id at 271-73.

${ }^{132}$ A creditor can go to a court and ask for an injunction against the wasting of corporate assets, but this process takes time, costs money, and is not certain to succeed. Thus, the uncertainty remains. 
signee is found. Although the assignee eventually will have to submit a long-form transfer-of-control application, the creditor will control the time it takes to find such an assignee in the first place. Hence she can make sure the application process begins quickly.

Increased control means more certainty of repayment as well as a smaller time period before repayment. In turn, these effects of the two-tier transfer of control process allow creditors to charge lower interest rates. Paying less money to borrow money reduces operations costs for the licensee. The FCC believes that licensees with lower expenses will provide better broadcasting services. ${ }^{133}$ Thus, implementing the two-tier procedure will allow the FCC better to serve the "public convenience, interest, or necessity."

Since the two-tier procedure is available to creditors that force a licensee into bankruptcy, one could argue that creditors can rely on this route to obtain the efficiencies created by this exception to the long-form transfer of control procedure. However, as the next section will show, creating different entitlements for creditors in bankruptcy than for creditors outside of bankruptcy creates its own inefficiencies.

3. The conflict with the FCC's accommodation policy.

Treating foreclosure outside of bankruptcy differently than foreclosure inside of bankruptcy conflicts with fundamental principles of the Bankruptcy Code. To create proper incentives, substantially similar policies must govern creditors' rights regardless of whether the debtor is in bankruptcy. Thus, adopting the two-tier approach for foreclosure outside of bankruptcy best suits the FCC's accommodation policy.

a) Policies underlying the Bankruptcy Code. Bankruptcy law operates on the theory that when the debtor does not have enough assets to go around, creditors that act as a group will recoup more of their investment than creditors that act on their own. ${ }^{134}$ Imagine, for example, a printing business in which the printing press is worth $\$ 100$ and the plates are worth $\$ 50$ if sold separately. However, if sold together, a buyer would be willing to pay $\$ 200$ for the same press and plates. The additional $\$ 50$ of value results from the synergistic effects of the assets: the printing company can only operate if it has both a press and plates.

${ }^{233}$ See text accompanying notes $41-43$.

134 Thomas H. Jackson, The Logic and Limits of Bankruptcy Law 10 (Harvard, 1986). 
If this business has one creditor, owed $\$ 200$, he will sell the press and plates together to maximize the selling price of the business. However, if the business has two creditors, each owed $\$ 100$, they may well act separately, with each creditor racing to foreclose on the press to sell it for $\$ 100$. Since each can keep no more than $\$ 100$, the individual creditor in this situation has no incentive to get the entire $\$ 200$ in value from a potential purchaser. Selling the assets separately results in an aggregate $\$ 50$ loss. In this situation, if Creditor 2 loses the race to the press, it should foreclose on the plates and bargain with Creditor 1 to sell both items to one buyer. However, bargaining is costly. After all, Creditor 1 will recoup all of its investment without dealing with Creditor 2. Since Creditor 2 benefits if it gets $\$ 1$ over the $\$ 50$ it would have gotten from selling just the plates, the parties will negotiate over the $\$ 50$ surplus. ${ }^{135}$

Bankruptcy policy is designed to avoid these costly negotiations by providing procedures that ameliorate the "common pool" problem described in the printing press example. ${ }^{136}$ These procedures give a group of creditors incentives to function as a single creditor. As one aspect of this policy, creditors can only force a debtor into bankruptcy when it is in the collective interests of the creditors as a group to do so. ${ }^{137}$

Having different entitlements inside and outside of bankruptcy encourages creditors to force the debtor into bankruptcy in order to obtain a benefit that would not otherwise be available to them. ${ }^{138}$ Imagine, for example, that the printing press business has only one creditor. Here, no common pool problem exists, and the creditor has incentives to maximize the value of the assets. But assume also that this business has recently been forced to enter into what the owner sees as unduly burdensome collective bargaining agreements. The creditor is unsure whether the business can operate profitably if bound by these agreements. If, for some reason, bankruptcy policy allowed this business to abrogate its em-

\footnotetext{
198 A race to the assets is also costly because creditors will have to monitor all other creditors to make sure no one is foreclosing on the assets.

${ }^{136}$ For a discussion of bankruptcy as a common pool problem see Douglas G. Baird and Thomas H. Jackson, Cases, Problems and Materials on Bankruptcy 39-43 (Little, Brown, $2 \mathrm{~d}$ ed 1990), and sources cited therein.

138 Jackson, The Logic and Limits of Bankruptcy Law at 21 (cited in note 134).

138 Morris G. Shanker, The Abuse and Use of Federal Bankruptcy Power, 26 Case W Res L Rev 3, 7 (1975). See also Jackson, The Logic and Limits of Bankruptcy Law at 21 (cited in note 134); and Jackson, 91 Yale L J at 904 (cited in note 104).
} 
ployment contracts inside of bankruptcy, the creditor would file an involuntary petition to put the firm into bankruptcy. ${ }^{139}$

The creditor would resort to bankruptcy not to solve the common pool problem for which the bankruptcy rules were created, but to obtain a benefit it could not have obtained outside of bankruptcy. The same is true for a broadcast lender that can obtain control of a station's assets faster by using the two-tier procedure only available in bankruptcy.

In order to create proper incentives for creditors to use the bankruptcy system for its designated purpose, a creditor's entitlements inside bankruptcy must not differ from those outside bankruptcy. The Supreme Court recognized this point in Butner $v$ United States, ${ }^{140}$ stating: "[u]niform treatment of property interests ... serves to reduce uncertainty, to discourage forum shopping, and to prevent a party from receiving 'a windfall merely by reason of the happenstance of bankruptcy." "141 To prevent this "windfall," the FCC should eliminate the incentive to force a creditor into bankruptcy currently created by the use of different transfer of control procedures.

Creating different entitlements inside of bankruptcy also creates instability. Although creditors have incentives to enter bankruptcy instead of foreclosing outside of bankruptcy, smaller creditors cannot know with certainty at the time they lend money that other creditors will in fact do so. These creditors will not know whether they will have to operate under bankruptcy rules or nonbankruptcy rules if the debtor defaults. Uncertainty increases interest rates. ${ }^{142}$ As one scholar explained, "[s]uch uncertainty regarding the applicable law on which parties may rely is hardly a situation which commends itself."

b) The conflict with FCC procedures. As explained above, the procedure used to transfer control to a station's creditor in bankruptcy is more advantageous to the creditor than the procedure used outside of bankruptcy. Creditors have incentives to force the licensee into bankruptcy so they can gain the increased certainty and control provided by the short-form/long-form procedure. These creditors use bankruptcy to gain substantive rights

139 This example is based loosely on In re Tinti Construction Co., Inc., 29 Bankr 971 (E D Wis 1983).

140440 US 48 (1979).

141 Id at 55, citing Lewis $v$ Manufacturers Nat. Bank, 364 US 603, 609 (1961).

142 See Section II.B.2.

${ }^{143}$ Shanker, 26 Case W Res L Rev at 8 (cited in note 138). See also Theodore Eisenberg, Bankruptcy Law in Perspective, 28 UCLA L Rev 953, 957 (1981). 
that they could not get by foreclosing outside of bankruptcy. These incentives hinder the collectivization function that underlies bankruptcy policy. Because creditors who know they will have access to the expedited transfer of control procedure upon default in bankruptcy charge less interest, it would make sense for the FCC to implement this procedure for default outside of bankruptcy.

As with security interests, then, deregulation and accommodation policies support changes in foreclosure procedures. Extending the two-tier transfer-of-control procedure outside of bankruptcy increases efficiency by decreasing the cost of borrowing. It would also make FCC policy consistent with bankruptcy policy by ensuring equal substantive rights for creditors of all debtors in default. Since the FCC sees deregulation and accommodation as the best ways to serve the public interest, its own policies justify these changes.

\section{Conclusion}

The FCC has done an admirable job of implementing its change in philosophy on how best to serve the public interest. Unfortunately, the Commissioners did not scrutinize broadcast financing regulations when they scrutinized the other FCC regulations for inefficiencies. Nor did they accommodate federal policies that affect broadcast finance. Recognizing security interests in licenses best suits the FCC's policies of favoring efficient regulation and accommodation of federal law. Giving all creditors access to the two-tier transfer of control process ensures efficient regulation and creates proper incentives for lenders. Broadcast financing should be the next step in the FCC's deregulation process. 